\title{
Status of micro irrigation systems adopted for vegetable cultivation in Polonnaruwa district, Sri Lanka
}

\author{
M. D. Udagedara and M. Sugirtharan
}

Department of Agricultural Engineering, Faculty of Agriculture, Eastern University Sri Lanka

\begin{abstract}
Micro-irrigation System (MIS) is proved to be an efficient method in saving water and increasing water use efficiency as compared to the conventional surface method of irrigation. However, use of MIS in Sri Lanka especially in the dryzone is very low. The present study was aimed to find the status of MIS adopted for vegetable cultivation in view of extending the cultivable land with MIS to increase the water use efficiency in five Divisional Secretariat (DS) division of Polonnaruwa district. Primary data were collected from 150 farmers using structured questionnaires, direct observation, field visit and personal interview. Results showed that, $17.3 \%$ of farmers adopted MIS in the study area. Most of MIS adopted farmers' family income was higher than the MIS not adopted farmers due to the reduction in labour cost and the selection of higher value crops for the cultivation. Most of MIS adopted farmers $(65.4 \%)$ were cultivating vegetable in both seasons and $88.5 \%$ of them pointed that their yield was increased by adopting MIS. Higher initial cost was the major drawback in implementing MIS system in the study area. Lack of capitals and knowledge were the major constrains for adopting MIS. Therefore, regular extension services, training program and supply of subsidies for establishment MIS are very essential in the study area to enhance the water use efficiency by adopting MIS.
\end{abstract}

Keywords: Vegetable cultivation, Micro irrigation, Surface irrigation, Water use efficiency.

\section{Introduction}

Increasing population in the world, increases the demand for food as well as the land area. Not only that, the food production in most of the developing countries is mainly based on agriculture crops. Therefore, the cultivable land area or productivity of land should be increased accordingly. As the limitation of land resources, productivity is the only possible way to supply the edible food to the rest of the population who are not cultivating the crops. Further, the population growth creates the demand for water which upsetting the ecological balance and drying up water supplies that ultimately lead to acute water shortage in the near future.

For centuries, agriculture has been a major occupation in Sri Lanka. Majority of the people in Sri Lanka had been engaged in vegetable cultivation. There are two main

types of vegetables grown in Sri Lanka based on geographical and climatic conditions. The upcountry vegetable constitutes crops such as cabbage, carrot, beet root, cauliflower, knolkhol, beans, tomato and capsicum which are grown in commercial scale with high input use. The other group constitutes the low country vegetables which include brinjal, chilli, bitter gourd, snake gourd, pumpkin and luffa which are cultivated less intensively under low input system (Bogahawatta, 2002).

On the other hand, the changes of rainfall pattern in Sri Lanka directly influence the fluctuation of the productivity of crop. Therefore, the crop which is cultivated 
depends on the irrigation water supplies. For the foreseeable future, irrigated agriculture will be the primary source of food and rural employment in Sri Lanka (Jayawardene et. al., 2005). Irrigation is generally defined as the application of water to soil for the purpose of supplying the moisture essential for plant growth (Vaughn et al., 1979). The most common irrigation techniques of today are basin, border strip, furrow and micro irrigation. Micro irrigation technology which is one of the improved irrigation technologies used in many parts of the world includes both drip and sprinkler irrigation technology (Ekanayake et al., 2015). Though, MIS has been introduced to the small farmers in Sri Lanka since 2000 to increase the crop productivity (Ekanayake et al., 2015), lack of comprehensive studies carried out regarding the problems and feasibility in adopting MIS specially in the dry zone of Sri Lanka.

In this view, the present study was conducted at Polonnaruwa District, which is a major agricultural area in the north central province of the Sri Lanka with the engagement of the traditional farmers who are lacking in new technologies. In this area, the low country vegetable crops are cultivated mostly under the surface irrigation including well water systems. Moreover, micro irrigation system is not popular among the farmers in Polonaruwa district due to the lack of knowledge and its functional benefits. Therefore, this study was formulated and aimed to understand the current status of the MIS and the factors influencing on adopting MIS in Polonnaruwa District, Sri Lanka.

\section{Materials and Methods}

\section{Location and description of the study area}

Polonnaruwa District is located in the North Central province of Sri Lanka. Annual rainfall ranges between $1180 \mathrm{~mm}$ $1800 \mathrm{~mm}$ in short period with long dry spell. Generally, average temperature is 28
${ }^{\circ} \mathrm{C}\left(82.4^{\circ} \mathrm{F}\right)$ and shows seasonal variation. Average temperature during December and January were found as approximately $27^{\circ} \mathrm{C}\left(80.6^{\circ} \mathrm{F}\right)$ and during the warmest months of the year from April through September it seemed $30-32{ }^{\circ} \mathrm{C}$ (CEA, 1990).

The study was conducted in five Divisional Secretariat (DS) Divisions of the Vegetable cultivation areas in Polonnaruwa District, namely Thamankaduwa, Hingurakgoda, Madirigiriya, Lankapura and Elahara areas covering $20 \mathrm{GN}$ divisions.

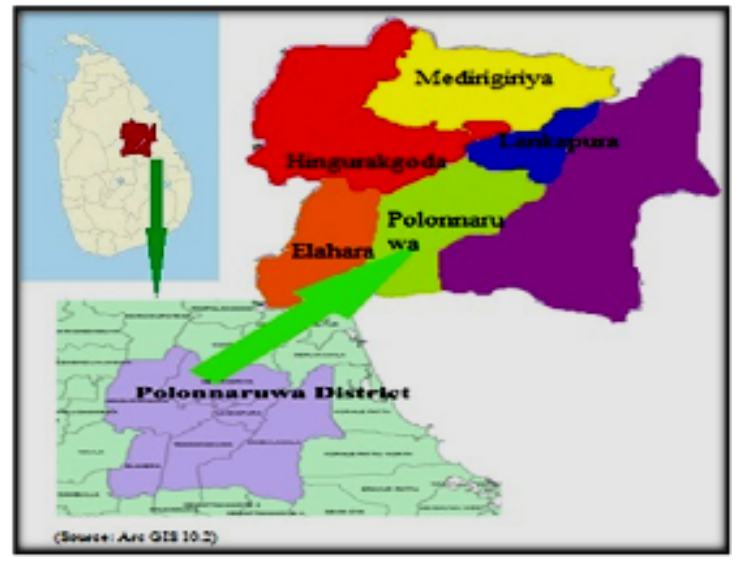

Figure 1: Location of study area

\section{Sampling and data collection}

Intensively vegetable cultivated areas in five DS divisions in Polonnaruwa district were purposely selected for this study. Among 402 registered vegetable farmers from the study area a total of 150 vegetable farmers were randomly selected for the survey from 5 DS divisions such as Thamankaduwa (20), Hingurakgoda (40), Madirigiriya (30), Lankapura (20) and Elahara (40).

Data required for the study were collected from a structured questionnaire survey, key informant interviews and direct field observations. Questionnaires were designed to collect data on farmer's awareness and factors influencing in adopting micro irrigation system in Polonnaruwa district during the period from August 2015 to February 2016. 
Further, socio economic condition of the farmers, information on cultivation, irrigation methods and problems in the MIS were also collected in the study.

Secondary data such as district statistical reports 2013-14 and published literatures were collected from Department of Agriculture, Agricultural Development Authority, and District Secretariat Office Polonnaruwa. Some data were collected by personal interview with Agriculture instructors who are working in the region.

\section{Sampling and data collection}

Intensively vegetable cultivated areas in five DS divisions in Polonnaruwa district were purposely selected for this study. Among 402 registered vegetable farmers from the study area a total of 150 vegetable farmers were randomly selected for the survey from 5 DS divisions such as Thamankaduwa (20), Hingurakgoda (40), Madirigiriya (30), Lankapura (20) and Elahara (40).

Data required for the study were collected from a structured questionnaire survey, key informant interviews and direct field observations. Questionnaires were designed to collect data on farmer's awareness and factors influencing in adopting micro irrigation system in Polonnaruwa district during the period from August 2015 to February 2016. Further, socio economic condition of the farmers, information on cultivation, irrigation methods and problems in the MIS were also collected in the study.

Secondary data such as district statistical reports 2013-14 and published literatures were collected from Department of Agriculture, Agricultural Development Authority, and District Secretariat Office Polonnaruwa. Some data were collected by personal interview with Agriculture instructors who are working in the region.

\section{Data Analysis}

Data were analyzed by using SPSS (Statistical Package for Social Science) software (version 19.0) for Windows. Data were confined to estimate frequencies and descriptive statistics.

\section{Results and Discussion}

The major findings on the status of MIS adoption among the vegetable farmers in the 5 DS divisions of the Polonnaruwa district are presented in this section.

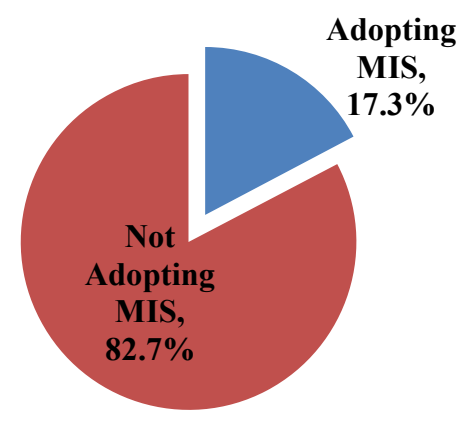

Figure 2: Adoption of micro irrigation
system among vegetable farmers

According to the Figure 2, Among the 150 vegetable farmers randomly selected in 5 DS divisions, around $17.3 \%$ of the farmers adopted MIS and $82.7 \%$ did not adopt that system. It was the overview of the current trend regarding the MIS adoption pattern in Polonnaruwa District, Sri Lanka.

\section{Socioeconomic characteristic of the vegetable farmers in study area}

The analyzed data showed (Table 1) that most of the vegetable farmers were within the age category of $36-45$ years. 
Table 1: Socio economic status of the farmers

\begin{tabular}{|c|c|c|c|}
\hline Category & & $\begin{array}{c}\text { MIS adopting farmers } \\
\left(\begin{array}{c}(\%) \\
(\mathrm{N}=26)\end{array}\right.\end{array}$ & $\begin{array}{c}\text { Non MIS adopting } \\
\text { farmers }(\%) \\
(\mathrm{N}=124)\end{array}$ \\
\hline Age (in years) & $\begin{array}{l}26-35 \\
36-45 \\
46-55 \\
56-65 \\
66-75\end{array}$ & $\begin{array}{c}15.4 \\
50.0 \\
11.5 \\
19.2 \\
3.8\end{array}$ & $\begin{array}{c}19.4 \\
32.3 \\
31.5 \\
14.5 \\
2.4\end{array}$ \\
\hline Sex & $\begin{array}{l}\text { Male } \\
\text { Female }\end{array}$ & $\begin{array}{c}88.5 \\
9.4\end{array}$ & $\begin{array}{c}93.5 \\
6.5\end{array}$ \\
\hline Marital status & $\begin{array}{l}\text { Married } \\
\text { Single } \\
\text { Divorced }\end{array}$ & $\begin{array}{c}100 \\
0 \\
0\end{array}$ & $\begin{array}{c}91.9 \\
5.6 \\
2.4\end{array}$ \\
\hline Occupation & $\begin{array}{l}\text { Government } \\
\text { Private } \\
\text { Day wage } \\
\text { Own business } \\
\text { Farmer } \\
\text { Other }\end{array}$ & $\begin{array}{c}18.8 \\
0 \\
12.5 \\
12.5 \\
37.5 \\
0\end{array}$ & $\begin{array}{c}5.6 \\
6.5 \\
13.7 \\
8.9 \\
56.5 \\
8.8\end{array}$ \\
\hline Education leve & $\begin{array}{l}\text { Higher } \\
\text { Advanced } \\
\text { Intermediate } \\
\text { Primary }\end{array}$ & $\begin{array}{c}26.9 \\
57.7 \\
15.4 \\
0\end{array}$ & $\begin{array}{c}2.5 \\
30.6 \\
54.8 \\
12.1\end{array}$ \\
\hline Monthly incon & $\begin{array}{l}\text { <e } \\
\text { <Rs.10000 } \\
\text { Rs.10000-Rs. } 20000 \\
\text { Rs.20,000-Rs. } 30000 \\
\text { Rs.30000-Rs. } 40000 \\
\text { Rs.40000-Rs. } 50000 \\
>\text { Rs. } 50000\end{array}$ & $\begin{array}{c}0 \\
19.2 \\
30.8 \\
30.8 \\
19.2 \\
0\end{array}$ & $\begin{array}{c}19.4 \\
42.7 \\
21.8 \\
11.3 \\
4.0 \\
0.8\end{array}$ \\
\hline
\end{tabular}

The age variable had a positive effect on the adoption probability of MIS. Normally, it is expected that the older farmers to have a lower chance of adoption of new innovations (Neil and Lee 2001; Madhava and surendran 2016). At the same time, most of the farmers were male however, less than $10 \%$ of the farm is owned by the female and they involved in some extent for farming activity and used hired labour for the day to day work at their farm.
It was also noticed that, farmers who were engaged in the government job (18.8\%) focused a lot on adopting micro irrigation system than the traditional methods of irrigation.

As far as the education level is concerned, the farmers who are educated above advanced level were practicing MIS at their farm. It is proved that the education level is determining the acceptance and implementation of new technologies for the production activities. 
The results also revealed that, average monthly income of the MIS adopting farmers was fairly higher than the farmers who were not Adopting MIS. Due to the reduced cost for labour, energy and the selection of higher value crops which ultimately led to the increased vegetable productions thus increasing income through adopting MIS in Polonnaruwa District, Sri Lanka. Income may also increase with the reduction in fertilizer application through MIS led to less leaching of the nutrients. Aheeyar et al., (2016) also reported that adoption of sprinkler system for irrigation has increased the net sown area, net irrigated area and cropping intensity, resulting in significant economic returns and welfare gains at the Kalpitiya area.

\section{Types of water source for irrigation}

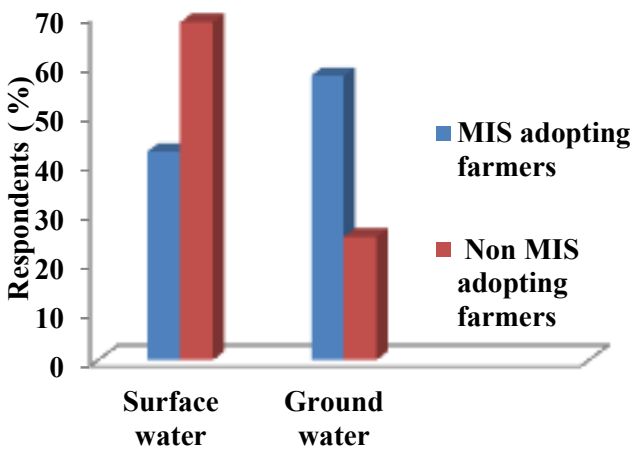

Figure 3: Type of water source used for irrigation

Surface water sources were highly used by farmers who were not adopting MIS $(68.5 \%)$ in Polonnaruwa District during the period of October, 2015 to February, 2016 whereas, ground water sources were the major water source for the MIS adopting vegetable farmers $(57.7 \%)$ while some farmers $(6.5 \%)$ among the MIS not adopting farmers were totally depends on rainfall. Farmers from both categories used tanks as the surface water source. Additionally, Open wells were mostly used by the farmers among ground water users for their cultivation systems in this district.

Majority of the farmers in both categories reported that there is sufficient amount of water for their vegetable cultivation. However, comparatively MIS non adoptive farmers are facing water problem than MIS adoptive farmers. It is obvious that, water use efficiency is greater in MIS and wastage is high in surface irrigation methods. Therefore, awareness programme on water use efficiency and the importance of MIS in saving water will attract more farmers to adopt MIS in the study area.

\section{Farmer's awareness on micro irrigation system}

Most of the vegetable farmers in the Polonnaruwa District were not well adopting to MIS (figure 2). However, $87.1 \%$ of the respondents mentioned that they have better awareness regarding the micro irrigation system. According to the scale of different, $4 \%, 24.2 \%$ and $58.9 \%$ were under the category of very well known, well known and somewhat known about the MIS, respectively. The higher percentage was occupied with somewhat known range which might also be a reason for the non-adoption of MIS system at study area.

Factors influencing on adopting MIS in study area

According to results, there are several factors influencing on adopting MIS in the study area. Among the MIS non adoptive farmers, around $50.7 \%$ have more than one reason for non-adoption mainly as lack of knowledge and lack of capital. Other than this, poor water quality $(8.9 \%)$, feeling risk for adopting new technology (2.4\%) and lack of willingness to follow the new and break the tradition $(8.9 \%)$ are some other reason for the non-adoption of MIS. 
Table 2: Factors influencing on the adoption of MIS

\begin{tabular}{lc}
\hline Factors & Percent $(\%)$ \\
\hline Lack of Knowledge & 6.5 \\
Lack of capital & 10.5 \\
Water quality problem & 8.9 \\
Feeling risk for adopting MIS & 2.4 \\
Do not like change traditional Methods & 8.9 \\
More than above two factors & 50.7 \\
Other factors & 12.1 \\
\hline
\end{tabular}

(Source: Data analysis, 2016)

Organizational support to establish the MIS in Study area

About $62.1 \%$ of the total respondents preferred to change their tradition to MIS, if any organization supports to establish MIS at their farm land. However, $37.9 \%$ of farmers did not prefer to establish MIS. The reasons given for that are; they are with the lack of knowledge (3.2\%), requirement of continuous maintenance that is difficult to them $(10.5 \%)$, thoughts on traditional way $(6.5 \%)$ and spreading of diseases $(4 \%)$. The reason given by them shows the lack of knowledge among the farmers regarding the MIS. It is obvious that some types of plants are not suitable to irrigate under sprinkler irrigation because of diseases or quality problems resulting from frequent wetting of the foliage. Higher humidity is mostly affected to fungal diseases such as white rust (Albugo candida), downey mildews and damping off. Other problems were created by rodents and insects, hence pest control methods may be necessary in such incidences.

Table 3: Organizational support to establish MIS

\begin{tabular}{lc}
\hline & Percent $\mathbf{( \% )}$ \\
\hline $\begin{array}{l}\text { (Question: Will you adopt MIS, if any organization } \\
\text { supports to establish MIS in you farm?) }\end{array}$ \\
Yes & \\
No & 62.1 \\
If No & 37.9 \\
Lack of Knowledge & \\
Need continuous maintain & 3.2 \\
Traditional thinking & 10.5 \\
Diseases spread through MIS & 6.5 \\
Other reasons & 4.0 \\
\hline
\end{tabular}

(Source: Data analysis, 2016)

\section{Type of micro irrigation system adopted}

Different kinds of traditional surface and micro irrigation systems have found in the study locations. Among the farmers who adopted MIS, $61.5 \%$ farmers practiced sprinkler system and $23.1 \%$ of farmers practiced both sprinkler and drip irrigation systems. Few farmers (15.4\%) have installed drip irrigation system at their farm in Polonnaruwa District. Most of the farmers preferred sprinkler irrigation system than the drip irrigation due to satisfaction on water delivery to the crop like rainfall. However, water application efficiency is high in drip irrigation system compared with the sprinkler irrigation. 


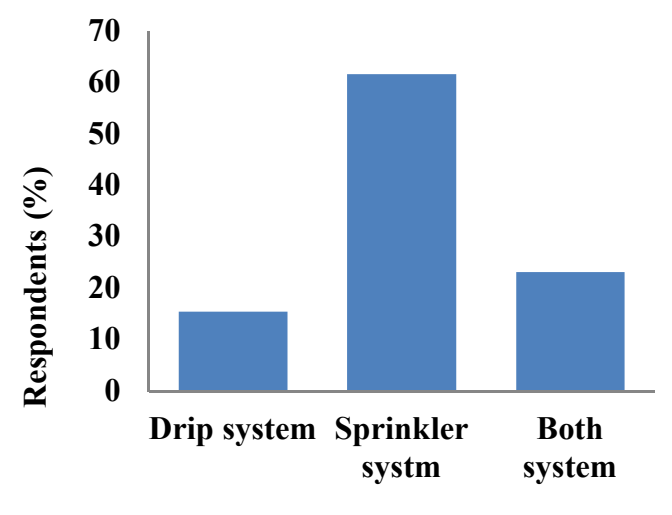

Type of MIS

Figure 4: Types of MIS adopted in study area

It also found that, around $23.1 \%$ of the total farmers gathered MIS related knowledge and information via the agricultural officers followed by private companies $15.4 \%$. In addition, learnt in school (7.7\%), other people $(11.5 \%)$, radio $(7.6 \%)$, television $(11.5 \%)$ and internet $(3.5 \%)$ were other sources of MIS related knowledge to the farmers. MIS adoptive farmers have good understanding on the impacts of micro irrigation system with the support of the organization or companies. Mainly these organization and companies provide the information on the micro irrigation systems, types of crop which can be cultivated under micro irrigation system and providing training opportunities about micro irrigation system.

\section{Vegetable cultivation under MIS in Polonnaruwa district}

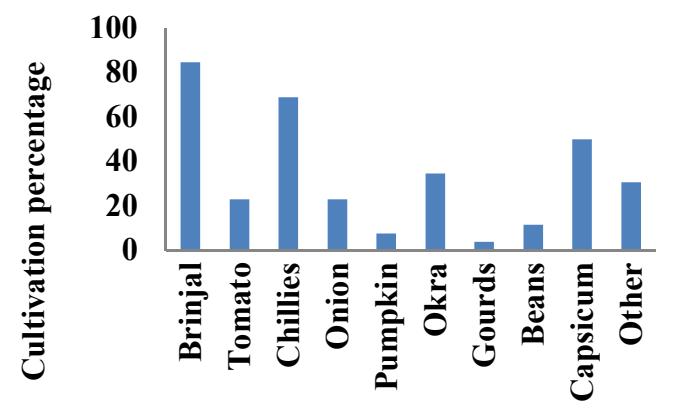

Figure 5: Vegetable cultivation under the micro irrigation system.
Figure 5 depicted that, approximately $84.6 \%$ of MIS adoptive farmers were used to cultivate Brinjal. Chilli, Capsicum and Okra were cultivated in large extent of cultivable areas with the respective value of $69 \%, 50 \%$ and $34.6 \%$, respectively. Other than this, Thibbatu (Solanum toroum) and Leafy vegetables were also cultivated by very few people under the MIS especially at the home garden level.

\section{Irrigation methods used before adopting MIS}

The above data describes that around $30.8 \%$ of the total MIS adopted farmers had used hose pipe as one of the irrigation methods before adopting to MIS. It was common to use bucket (26.9\%), Ridge and furrow irrigation (19.2\%) and the basin type of irrigation methods $(7.7 \%)$ in all the cultivable areas and home gardens.

Table 4: Previous irrigation methods

\begin{tabular}{lc}
\hline Irrigation method & Percent (\%) \\
\hline Using hose pipe & 30.8 \\
Using buckets & 26.9 \\
Ridge and furrow type & 19.2 \\
Basin type & 7.7 \\
Border irrigation & 15.4 \\
\hline
\end{tabular}

Many of the farmers (34.6\%) had changed to MIS within two years period of time. It was also noticed that the trend of adopting MIS is now increasing. Availability of labour, labour cost and water may be the major reason for shifting to MIS at the study area.

Facts behind the adoption of MIS by the farmers

Results revealed that the numbers of influencing factors are higher to move on MIS in Polonnaruwa District, Sri Lanka. The combination of the following facts were the leading reasons to the great movement towards MIS. The extension services $(11.5 \%)$ which were given by some of the Agricultural Departments and other organization, reduce the cost for labors 
(3.8\%) and less water requirement (11.5\%) and higher yield $(7.7 \%)$ are some of the reason given by MIS adoptive farmers to motivate them to the MIS. They further reported that due to the high water use efficiency they increase the extent of land for the cultivation under MIS using same amount of water allocated before the adoption of MIS. After adoption of MIS, the farmer himself manage the irrigation, which deserve 3 hours of time per day which reduces labour cost of Rs 1200 per day spent for the irrigation.

Table 5: Reason for moving towards the MIS

\begin{tabular}{|c|c|}
\hline Reasons & $\begin{array}{l}\text { Percent } \\
(\%)\end{array}$ \\
\hline Less labor cost & 3.8 \\
\hline Assisted by NGO & 7.7 \\
\hline $\begin{array}{l}\text { Encouragement agricultural } \\
\text { extension services }\end{array}$ & 11.5 \\
\hline $\begin{array}{l}\text { Reduce the water } \\
\text { requirement }\end{array}$ & 11.5 \\
\hline To increase yield & 7.7 \\
\hline $\begin{array}{l}\text { More than one above } \\
\text { reasons }\end{array}$ & 50.1 \\
\hline Other reasons & 7.7 \\
\hline
\end{tabular}

Further, $22.9 \%$ of the respondents stated as, it is a profitable system and fertilizer would be applied through micro irrigation system which is another advantages achieved by farmers through MIS. Aheeyar (2005) reported that, fertigation reduces fertilizer cost by $30-50 \%$ compared to conventional methods since they are applied directly to the root zone by this method.

The study also tried to gather the information from the MIS adoptive farmers about the yield comparison between the cultivation with traditional way and the MIS. Based on that, $65.4 \%$, $3.8 \%$ and $30.8 \%$ of the MIS adoptive farmers reported that their yield has increased, decreased and no change in yield, respectively.

\section{General opinion of MIS adopting farmers}

Table 6 gives the general views of the MIS adoptive farmers in the study area with the valid percentages.

1- Definitely true 2 - True most of time

3 - Neutral 4-Somewhat false

5- definitely false 6- Don't know

Table 6: General views of farmers adopting MIS

\begin{tabular}{|c|c|c|c|c|c|c|}
\hline \multirow[t]{2}{*}{ Information } & \multicolumn{6}{|c|}{ Percent (\%) } \\
\hline & 1 & 2 & 3 & 4 & 5 & 6 \\
\hline $\mathbf{S}_{1}$ Yield was increased & 65.4 & 19.2 & 15.4 & 0 & 0 & 0 \\
\hline $\mathbf{S}_{2}$.Crop quality was increased & 73.1 & 23.1 & 3.8 & 0 & 0 & 0 \\
\hline $\mathbf{S}_{3 . L e s s}$ water was applied & 73.1 & 26.9 & 0 & 0 & 0 & 0 \\
\hline $\mathbf{S}_{4}$ Less electricity or power was used & 73.1 & 23.1 & 3.8 & 0 & 0 & 0 \\
\hline $\mathbf{S}_{5 .}$ Overall farming was easier & 38.5 & 46.2 & 15.4 & 0 & 0 & 0 \\
\hline $\mathbf{S}_{6 .}$ Less weeds or control was easier & 15.4 & 26.9 & 46.2 & 11.5 & 0 & 0 \\
\hline S $_{7}$ More sophisticated labor was required & 7.7 & 15.4 & 38.5 & 11.5 & 19.2 & 7.7 \\
\hline $\mathbf{S}_{8 .}$ Labor cost was decreased & 80.8 & 15.4 & 3.8 & 0 & 0 & 0 \\
\hline $\mathbf{S}_{9}$.Irrigation was easy & 88.5 & 7.7 & 3.8 & 0 & 0 & 0 \\
\hline $\mathbf{S}_{10 .}$ Less insect damage or control was easy & 26.9 & 15.4 & 26.9 & 11.5 & 11.5 & 7.7 \\
\hline $\begin{array}{l}S_{11} \text { Less Diseases/fungus or control was } \\
\text { easy }\end{array}$ & 15.4 & 11.5 & 11.5 & 26.9 & 23.1 & 11.5 \\
\hline $\mathbf{S}_{12 .}$ Rodent / animals problems was less & 69.2 & 11.5 & 7.7 & 7.7 & 3.8 & 0 \\
\hline$S_{13}$. Considering all factors have benefits & 88.5 & 3.8 & 7.7 & 0 & 0 & 0 \\
\hline
\end{tabular}


S1: Most of the respondents (65.4\%) have got increased yield due to the sufficient amount of water at the root zone where the soil always maintained in the field capacity and also plant growth without water stress. Therefore, plant shows optimum Performance.

S2, S3, S4: Approximately, $73.1 \%$ of the farmers represented as it definitely true about the increased crop quality with an application of water in an efficient way and mentioned that they used less electricity or power. Through the MIS adoption, water was saved upto $40-50 \%$ compared to surface irrigation, without any significant reduction in yield. Raina et al., (1998) reported that, it is possible to irrigate an additional one-hectare of land from the saved water and thereby increasing net income.

S5, S6: About $46.2 \%$ of respondents represented that the overall farming activities were easier in most of the times and also $46.2 \%$ of respondent's neutral response about the less weeds or easier of control.

S7: About $38.5 \%$ of farmers answered neutral about requirement of sophistic labor for maintaining MIS.

S8, S9: Most of the farmers (80.8\%) answered definitely true about the labor cost reduction through adopting MIS and also $(88.5 \%)$ answered that the irrigation was easier through adopting MIS. The conveyance efficiency under the surface method of irrigation was estimated to be only in the range of $40-50 \%$ in canal and 60 $70 \%$ in well, the same was estimated to be $100 \%$ in both sprinkler and drip method of irrigation (Aswathy et al., 2014)

S10: Nearly $26.6 \%$ of farmers represented definitely true and neutral, both answers about less insect damage through adopting MIS.
S11: Most of the farmers (26.9\%) represented somewhat false about less diseases and fungus or easy to control through adopting MIS. Because most of farmers have faced fungal diseases due to the higher humidity conditions of surrounding plant canopy areas.

S12: Around 69.2\% farmers represented definitely true about rodent and animal damage was reduced through the adoption of the MIS

S13: Approximately $88.5 \%$ of farmers represented definitely true about all the factors MIS adoption has been benefitted to them. Most of farmers have benefits such as higher yield, less water requirement; reduce the labor cost and energy cost.

Yield comparison based on the irrigation system.

The use of micro-irrigation technologies increasing crop yields by $20-90 \%$ (Postel, 1999; Suryawanshi, 1995). Similarly, in the present study, most vegetables showed increased yield but beans and Pumpkin showed low yield under MIS. Brinjal, Chilli, Okra and Capsicum also showed yield increase in micro irrigation adopting farmers in Pollonnaruwa district (Table 7).

Table 7: Yield variation according to MIS

\begin{tabular}{lcc}
\hline Crop & $\begin{array}{c}\text { Farmer } \\
\text { adopting } \\
\text { MIS } \\
\text { Mean(Kg) }\end{array}$ & $\begin{array}{c}\text { Farmers not } \\
\text { adopting } \\
\text { MIS } \\
\text { Mean(Kg) / } \\
\text { ac }\end{array}$ \\
\hline Brinjal & 4605.76 & 1202.41 \\
Tomato & 663.46 & 440.96 \\
Chilli & 2051.92 & 678.87 \\
Onion & 4346.15 & 2971.77 \\
Pumpkin & 226.92 & 372.016 \\
Okra & 609.61 & 492.33 \\
Gourds & 500.00 & 159.91 \\
Beans & 398.84 & 403.62 \\
Capsicum & 2005.76 & 402.82 \\
\hline
\end{tabular}




\section{Limitation in using MIS}

According to the Table 8, most of the farmers $(26.9 \%)$ faced problems regarding the poor water quality. Services provided by the company who establish MIS is very less therefore they spend higher cost to solve problems in the study site.

Table 8: Limitation in using MIS

\begin{tabular}{llc}
\hline Limitations & $\begin{array}{c}\text { Percent } \\
(\mathbf{\%})\end{array}$ \\
\hline $\begin{array}{l}\text { Poor water quality } \\
\text { Designing difficult }\end{array}$ & 26.9 \\
sloppy area & & 7.7 \\
$\begin{array}{l}\text { Technology needed } \\
\text { Higher cost }\end{array}$ & & 11.5 \\
$\begin{array}{l}\text { Traditional thinking not } \\
\text { allowed }\end{array}$ & 3.8 \\
$\begin{array}{l}\text { Service from company is } \\
\text { poor than above one }\end{array}$ & 19.2 \\
$\begin{array}{l}\text { More than } \\
\text { limitation }\end{array}$ & & \\
\hline
\end{tabular}

Higher initial cost is another disadvantage among the MIS adopted farmers. Technical knowledge required for maintenance and higher price of MIS parts were other limitations pointed by the farmers. The studies conducted in different parts of India found that the major factors hindering the uptake of micro-irrigation technologies are the high initial capital investment required; lack of credit facilities and information (Narayanamoorthy 1997; Sivanappan 1988; Dhawan 2000); capital intensiveness of the conventional microirrigation technologies (Puranik et al., 1992); inadequate awareness of water scarcity; lack of skilled human resources for the repair and maintenance of the equipment used, and non-availability of spare parts (Devi et al, 2012).

\section{Conclusions}

Adoption of micro irrigation system for the vegetable cultivation is very low in Polonnaruwa district. Lack of capital and knowledge were the major constrains for adopting MIS. The farmer's interest to adopt MIS in Pollonnaruwa district can be increased by improving extension services, subsidies by organization or government to establish MIS, supply loan for the MIS farmers, organize field visit to encourage farmers and facilitate training program to farmers. Reduced cost for equipment price of micro irrigation systems and spare parts may also attract more farmers to adopt the MIS for the vegetable cultivation. Adoption of MIS in the Polonaruwa district will help to save water and increase cultivable area to produce more food and contribute to supply for the food requirement of increased population growth of Sri Lanka.

\section{References}

Aheeyar, M.M.M., Kumara, S.K. and Samarasinhe, G.G. (2005). Application of Micro Irrigation Technologies in Sri Lanka: Potentials and Constraints, Research Report No: 113, Hector Kobbekaduwa Agrarian Research and Training Institute, Colombo, Sri Lanka

Awasthy, P., Patel, B., Sahu, P., Patanwar, M., \& Sahu, P. K. (2014). International Journal of Agricultural and Food Science

Bogahawatta, S. L. (2002), Country Report on Horticulture Production in Sri Lanka, SriLanka.

CEA, (1990), An Enviornmental profile of the Polonnarywa district. Central Environmental Authority, Sri Lanka.

Devi, I.P.; Shanmugasundaram and Prema, A. (2012). Micro-irrigation: Economics and outreach in Kerala, In K. Palanisami et al. (ed.), Micro-irrigation economics and outreach, Macmillan publishers, New Delhi, pp 94-119.

Dhawan, B.D. (2000). Drip Irrigation: Evaluating Returns, Economic and Political Weekly, pp 3775-3780, October 14.

Ekanayake E.M.T, Gunaratne, L.H.P. and E.R.N. Gunawardena (2015), Technical and socio economic assessment of micro irrigation systems in the small scale 
farming sector of Sri Lanka. Tropical Agricultural Reseach Volume 18.

Jayawardene, H.K.W.I., Sonnadara. D.U.J. and D.R. Jayewardene (2005), Trends of Rainfall in Sri Lanka over the Last Century. Sri Lankan Journal of Physics, Vol.6 (2005) 7-17

Madhava Chandran,K and U. Surendran (2016), Study on factors influencing the adoption of drip irrigation by farmers in humid tropical Kerala, India. International Journal of Plant Production 10 (3).

Mohamed Aheeyar, Herath Manthrithilake and Selvarajah Pathmarajah (2016). Drivers of the Adoption of Farmer-innovated Sprinkler IrrigationSystems: Evidence from Kalpitiya, Sri Lanka. International Perspective on Water Resources and the Environment, Colombo, Sri Lanka, January 4-6, 2016.

Narayanamoorthy, A. (1997). Economic Viability of Drip Irrigation: An Empirical Analysis from Maharashtra. Indian Journal of Agricultural Economics Vol. 52, No. 4. Pp 728-739.

Neil S.P, Lee D.R (2001) Explaining the adoption and disadoption of sustainable agriculture: the case of cover crops in northern Honduras. Econ Dev Cult Change 49(4):793-820

Postel S., (1999), Pillar of Sand: Can the Irrigation Miracle Last?, World Watch, New York, W.W.Norton \& Company.

Puranik, R. P., Khonde, S. R., and Ganorkar, P. L., (1992), Constraints and problems as perceived by nonadopters and adopters of drip irrigation systems, Agricultural Situation in India, Vol. XLVII, No. 1, Apr. pp. 33-34.

Raina, J. N., Thakur, B. C., \&Bhandari, A. R. (1998).Effect of drip irrigation and plastic mulch on yield, water use efficiency and benefit-cost ratio of pea cultivation.Journal of the Indian Society of Soil Science, 46(4), 562-567.

Sivanappan, R. K., (1988), Use of plastics in drip irrigation, Moving Technology, 3(4), pp. 7-9.

Suryawanshi S. K., (1995), Success of Drip in India: An Example to the Third World, in F. Lamm (ed.), Micro-irrigation for Changing World, Proceedings of the Fifth International Micro-irrigation Congress, St Joseph, MI, American Society of Agricultural Engineers.

Vaughn E. Hansen. (1979). Irrigation principles and practices. Forth edition Printed the USA.ppl-13. 